Article

\title{
Efficacy of Reduced Rates of Soil-Applied Dimethenamid-P and Pendimethalin Mixture Followed by Postemergence Herbicides in Maize
}

\author{
Robert Idziak * and Zenon Woznica \\ Department of Agronomy, Poznan University of Life Sciences, Dojazd 11, 60-632 Poznan, Poland; \\ zenon.woznica@up.poznan.pl \\ * Correspondence: robert.idziak@up.poznan.pl; Tel.: +48-61-848-7598
}

Received: 8 April 2020; Accepted: 9 May 2020; Published: 11 May 2020

\begin{abstract}
Field trials were conducted with preemergence dimethanamid-P + pendimethalin $(\mathrm{D}+\mathrm{P}$; $\left.850+1000 \mathrm{~g} \cdot \mathrm{ha}^{-1}\right)$ and reduced rates $\left(637.5+750 \mathrm{~g} \cdot \mathrm{ha}^{-1}\right.$ and $452+500 \mathrm{~g} \cdot \mathrm{ha}^{-1}, 75 \%$ and $50 \%$ of label rate), followed by strongly reduced rates of postemergence herbicides nicosulfuron + rimsulfuron + dicamba $\left(\mathrm{N}+\mathrm{R}+\mathrm{D} ; 4+15.6+93.5 \mathrm{~g} \cdot \mathrm{ha}^{-1}, 50 \%\right)$, tembotrione $\left(\mathrm{T} ; 33 \mathrm{~g} \cdot \mathrm{ha}^{-1}, 50 \%\right)$, mesotrione + nicosulfuron $\left(\mathrm{M}+\mathrm{N} ; 37.5+15 \mathrm{~g} \cdot \mathrm{ha}^{-1}, 50 \%\right)$, foramsulfuron + iodosulfuron $(\mathrm{F}+\mathrm{J}$; $\left.7.5+0.25 \mathrm{~g} \cdot \mathrm{ha}^{-1}, 20 \%\right)$, and nikosulfuron ( $\mathrm{N} ; 15 \mathrm{~g} \cdot \mathrm{ha}^{-1}, 33 \%$ ) applied with methylated seed oil (MSO; $1.0 \mathrm{~L} \cdot \mathrm{ha}^{-1}$ ) and ammonium nitrate (AMN; $2 \mathrm{~kg} \cdot \mathrm{ha}^{-1}$ ) on 3-5 leaves of maize to assess weed control, grain yield, and economic net return. Reduced rate of soil-applied herbicide followed by reduced rates of any postemergence herbicides applied with adjuvants was the most efficacious weed control program, provided the highest grain yield of maize and similar or higher economic net return, despite 44 to $48 \%$ lower herbicide input than the program based on soil-applied herbicide mixture only. It brings not only notable economic benefits but also less negative impact on the environment.
\end{abstract}

Keywords: adjuvant; herbicide; maize; weed control; economic index

\section{Introduction}

Maize is one of the most important crops all over the world, including Poland [1,2]. Maize plants, due to their competitive weakness against weeds, are especially exposed to yield losses [3,4]. During the critical period of competition in maize, from 1 to 15 leaf stages, weeds can cause yield losses from $12 \%$ to $70 \%$, even $85 \%$ [5-9]; therefore, weed control in maize is necessary and essentially consists of herbicide application. Use of herbicides is the most effective method $[10,11]$ but may negatively affect crop quality [12] and has an adverse effect on the natural environment [13]; furthermore, widely used herbicides can contribute to the selection of resistant weeds [14]. Generally, weed control in maize bases on a single herbicide application during crop vegetation $[15,16]$ and a choice of pre- or postemergence application depends on the current situation on field and a farmer's decision. Herbicide activity is limited in time and, most often, is not good enough to control weeds appearing during the secondary infestation, weeds which primarily may interfere with harvesting and reduce harvestable yields [17]. Lots of emphasis should be put on herbicide choice to prevent herbicide resistance. It should consist of at least two active ingredients having a different site of action, and it should take into account the weed community composition [18]. Some studies $[19,20]$ indicate advisability of the use of postemergence split application of herbicide mixtures when weeds are most sensitive at the stage from cotyledons to the first pair of leaves. A split application consists of preemergence and postemergence treatments that should provide more consistent weed control because early season weed control is vital to both future yields and profitability since early weeds compete intensely with maize. A clean field at planting 
is crucial for starting the maize crop, and preemergence herbicides help to both start the maize off clean and to reduce the potential development of weeds [21,22]. Preemergence application keeps late-emerging weeds small during the first weeks after treatment, but when their activity declines, new-emerging weeds occur and postemergence herbicides must be applied for optimal weed control as they can also be very competitive. A split application is related to a higher cost of weed control and additional operations [23]. Optimisation of weed control in maize should reduce the cost of application as well as the amount of pesticides delivered to the environment and should keep great weed control [24]. Preemergence herbicides should cover a broad spectrum of weeds to keep the field clean at the beginning and during the first weeks after sowing [22]. Postemergence herbicides are used when new weeds appear later in the growing season, and they are more controlled and for longer by herbicides with different modes of action [25], applied at reduced rates with appropriate adjuvant [26]. Herbicides tested in the present study belong to a different group and are commonly used because of their broad-spectrum weed control, flexible application timing, tank-mix compatibilities, and crop safety.

The objective of the study was to determine the impact of split application of preemergence applied herbicides (dimethanamid-P + pendimethalin) at reduced rates and postemergence applied herbicide (nicosulfuron + rimsulfuron + dicamba, tembotrione, mesotrione + nicosulfuron, foramsulfuron + iodosulfuron, and nicosulfuron) at strongly reduced rates, used with methylated seed oil adjuvants and ammonium nitrate on weed control, grain yield, and net return.

\section{Materials and Methods}

Field trials were carried out in 2013 and 2014 at the Poznan University of Life Sciences Research and Education Center (REC) in Brody ( $\left.52^{\circ} 25^{\prime} \mathrm{N}, 16^{\circ} 18^{\prime} \mathrm{E}\right)$, Poland. The soil at site was Luvisols (Marcinek et al. 2011). Plant, soil, and herbicide application dates are presented in the Table 1.

Table 1. Soil characteristics, maize hybrid, planting and harvest dates, seed rates, and application time for field studies carried out in Brody, PL in 2013 and 2014.

\begin{tabular}{|c|c|c|c|c|c|c|c|c|}
\hline \multirow{2}{*}{ Year } & \multirow{2}{*}{$\begin{array}{c}\text { Soil } \\
\text { Texture }\end{array}$} & \multirow{2}{*}{$\begin{array}{c}\text { Soil OM } \\
\%\end{array}$} & \multirow{2}{*}{$\begin{array}{l}\text { Soil } \\
\mathrm{pH}\end{array}$} & \multirow{2}{*}{$\begin{array}{l}\text { Maize } \\
\text { Hybrid }\end{array}$} & Planting & Harvest & \multirow{2}{*}{$\begin{array}{l}\text { Seed Rate } \\
\text { No. ha-1 }\end{array}$} & \multirow{2}{*}{$\begin{array}{l}\text { Application } \\
\text { Time }\end{array}$} \\
\hline & & & & & & Date & & \\
\hline 2013 & $\mathrm{LS}^{2}$ & 1.0 & 5.9 & P8100 & April 30th & September 27th & 80,000 & $\begin{array}{l}\text { May 2nd } \\
\text { June 4th }\end{array}$ \\
\hline 2014 & LS & 1.2 & 6.1 & PR39H32 & April 22nd & September 22nd & 80,000 & $\begin{array}{l}\text { April 22nd } \\
\text { June 16th }\end{array}$ \\
\hline
\end{tabular}

Maize cultivars each year were planted in the last 10 days of April. Field experiment was arranged in a randomized complete block design with four replications. The individual plots were $5 \mathrm{~m}$ long and $2.5 \mathrm{~m}$ wide $\left(12.5 \mathrm{~m}^{2}\right)$; each of the 32 plots contained 4 rows spaced $70 \mathrm{~cm}$ apart. The previous crop in 2013 was winter wheat and spring barley in 2014. Experimental fields were moldboard plowed in the fall and shallow cultivated in the spring prior to planting. Mineral fertilization, according to plant needs and nutrient content in the soil, consisted of $60 \mathrm{~kg} \mathrm{P}$ and $\mathrm{K} \mathrm{ha}^{-2}$ applied in the fall. Nitrogen at $140 \mathrm{~kg} \cdot \mathrm{ha}^{-1}$ was applied before planting at $80 \mathrm{~kg} \cdot \mathrm{ha}^{-1}$ and at 2-3 leaf stages of maize: $60 \mathrm{~kg} \cdot \mathrm{ha}^{-2}$.

Treatments included herbicide dimethanamid-P + pendimethalin (D + P, Wing P 462.5 EC, BASF SE, Ludwigshafen, Germany) applied once (0) at label rate $850+1000 \mathrm{~g} \cdot \mathrm{ha}^{-1}$ and reduced rates $637.5+750 \mathrm{~g} \cdot \mathrm{ha}^{-1}$ and $452+500 \mathrm{~g} \cdot \mathrm{ha}^{-1}$ (respectively, 75 and $50 \%$ of label rate). Herbicide D + P was applied preemergence. Herbicide application consisted of D $+\mathrm{P}$ at $452+500 \mathrm{~g} \cdot \mathrm{ha}^{-1}$ and postemergence herbicides (A) applied at strong reduced rates, such as nicosulfuron + rimsulfuron + dicamba (N+R + D, Hector Max 66.5 WG, Du Pont International Operations Sarl., Geneva, Switzerland) at $4.0+15.6+93.5 \mathrm{~g} \cdot \mathrm{ha}^{-1}$ ( $50 \%$ of label rate), tembotrione (T, Laudis $44 \mathrm{OD}$, Bayer CropScience, Monheim, Germany) at $33 \mathrm{~g} \cdot \mathrm{ha}^{-1}$ ( $50 \%$ of label rate), mesotrione + nicosulfuron ( $\mathrm{M}+\mathrm{N}$, Elumis 105 OD, Syngenta Crop Protection AG, Bazylea, Switzerland) at $37.5+15$ g.ha ${ }^{-1}$ (50\% of label 
rate), foramsulfuron + iodosulfuron ( $\mathrm{F}+\mathrm{I}$, Maister $31 \mathrm{OD}$, Bayer CropScience, Lyon, France) at

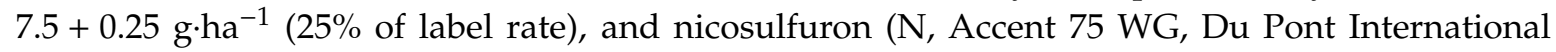

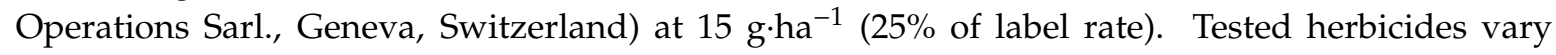
according to mode of action and belong to different HRAC (Herbicide Resistance Action Committee) groups: K3-dimethanamid-P; K1—pendimethlin; B-nikosulfuron, rimsulfuron, formasulfuron, and iodosulfuron, $\mathrm{O}$-dicamba; and F2—tembotrione and mesotrione. Postemergence herbicides with addition of emulsified methylated seed oil (MSO, Atpolan BIO 80 EC, ZPH Agromix, Niepolomice, Poland) at $1.0 \mathrm{~L} \cdot \mathrm{ha}^{-1}$ based on rapeseed oil fatty acids with a build-in surfactant and $\mathrm{pH}$ buffer, buffering $\mathrm{pH}$ of the liquid spray at the level of 7.3-7.8, and ammonium nitrate (AMN, 34\% N, Anwil Grupa Orlen, Wloclawek, Poland) at $2 \mathrm{~kg} \cdot \mathrm{ha}^{-1}$ were applied at the stage of 3-5 maize leaves when most dicotyledonous weeds were at the 2-4 leaf stages and barnyard grass from the 3-leaf stage to the end of flowering. Untreated control plots were included in randomization.

Tested herbicides were applied with $\mathrm{CO}_{2}$-pressurized sprayer equipped with flat fan nozzles Teejet XR 11002 VS (2013) and TeeJet DG 11002 VS (2014) calibrated to deliver $230 \mathrm{~L} \cdot \mathrm{ha}^{-1}$ at $0.22 \mathrm{MPa}$. Herbicide treatments were made with $2.5 \mathrm{~m}$ boom equipped with five nozzles spaced $50 \mathrm{~cm}$ apart. In 2013, temperatures during the first and second applications were, respectively, $11.2^{\circ} \mathrm{C}$ and $16.0^{\circ} \mathrm{C}$ and humidity was $79 \%$ and $81 \%$ and, in 2014 , temperatures were $19.8^{\circ} \mathrm{C}$ and $17.9^{\circ} \mathrm{C}$ and humidity was $45 \%$ and $37 \%$, without any rainfall on application days. Average temperatures after treatments in the year 2013 amounted to $11.3-19.5^{\circ} \mathrm{C}$ and $12.6-19.5^{\circ} \mathrm{C}$ and, in 2014 , ranged from 12.2 to $14.8^{\circ} \mathrm{C}$ and 12.6-17.0 ${ }^{\circ} \mathrm{C}$ (Table 2).

Table 2. Meteorological data at the Research and Education Center Brody during and after spray application in 2013 and 2014.

\begin{tabular}{|c|c|c|c|c|c|c|c|c|c|c|}
\hline \multicolumn{11}{|c|}{ Application time: 2 May 2013} \\
\hline \multicolumn{3}{|c|}{ Temperature: $11.2^{\circ} \mathrm{C}$} & \multicolumn{4}{|c|}{$\begin{array}{c}\text { Air humidity: } 79 \% \\
\text { Temperature after treatment }\end{array}$} & \multicolumn{4}{|c|}{ Rainfall: $0.0 \mathrm{~mm}$} \\
\hline Date & $2 / 05$ & $3 / 05$ & $4 / 05$ & $5 / 05$ & $6 / 05$ & $7 / 05$ & $8 / 05$ & $9 / 05$ & $10 / 05$ & $11 / 05$ \\
\hline Mean & 11.3 & 11.9 & 14.9 & 15.8 & 15.1 & 17.3 & 19.5 & 17.8 & 15.3 & 13.7 \\
\hline Minimum & 7.1 & 8.7 & 10.0 & 10.9 & 7.1 & 10.4 & 11.7 & 9.9 & 13.4 & 10.9 \\
\hline \multicolumn{5}{|c|}{$\begin{array}{l}\text { Total rain in last week before treatment: } 3.8 \mathrm{~mm} \\
\text { First rainfall after treatment, date: } 06 / 05 / 2013\end{array}$} & \multicolumn{6}{|c|}{$\begin{array}{l}\text { Total rain in 1st week after treatment: } 0.2 \mathrm{~mm} \\
\text { Total rain in 2nd week after treatment: } 17.0 \mathrm{~mm} \\
\text { Total rain in 3rd week after treatment: } 0.1 \mathrm{~mm} \\
\text { Total rain in 4th week after treatment: } 20.7 \mathrm{~mm}\end{array}$} \\
\hline \multicolumn{11}{|c|}{ Application time: 4 June 2013} \\
\hline \multicolumn{3}{|c|}{ Temperature: $16.0^{\circ} \mathrm{C}$} & \multicolumn{4}{|c|}{$\begin{array}{c}\text { Air humidity: } 81 \% \\
\text { Temperature after treatment }\end{array}$} & \multicolumn{4}{|c|}{ Rainfall: $0.0 \mathrm{~mm}$} \\
\hline Date & $4 / 06$ & $5 / 06$ & $6 / 06$ & $7 / 06$ & $8 / 06$ & $9 / 06$ & $10 / 06$ & $11 / 06$ & $12 / 06$ & $13 / 06$ \\
\hline Mean & 14.1 & 12.6 & 15.4 & 18.2 & 19.2 & 18.6 & 16.6 & 16.1 & 17.6 & 19.5 \\
\hline Minimum & 10.8 & 7.0 & 8.9 & 12.0 & 12.9 & 14.7 & 11.0 & 7.1 & 7.9 & 9.8 \\
\hline \multicolumn{5}{|c|}{$\begin{array}{l}\text { Total rain in last week before treatment: } 57.8 \mathrm{~mm} \\
\text { First rainfall after treatment, date: } 10 / 06 / 2013\end{array}$} & \multicolumn{6}{|c|}{$\begin{array}{l}\text { Total rain in 1st week after treatment: } 1.1 \mathrm{~mm} \\
\text { Total rain in 2nd week after treatment: } 0.3 \mathrm{~mm} \\
\text { Total rain in 3rd week after treatment: } 0.3 \mathrm{~mm} \\
\text { Total rain in } 4 \text { th week after treatment: } 109.1 \mathrm{~mm}\end{array}$} \\
\hline
\end{tabular}


Table 2. Cont.

\begin{tabular}{|c|c|c|c|c|c|c|c|c|c|c|}
\hline \multicolumn{11}{|c|}{ Application time: 22 April 2014} \\
\hline \multicolumn{3}{|c|}{ Temperature: $19.8^{\circ} \mathrm{C}$} & \multicolumn{4}{|c|}{$\begin{array}{c}\text { Air humidity: } 45 \% \\
\text { Temperature after treatment }\end{array}$} & \multicolumn{4}{|c|}{ Rainfall: $0.0 \mathrm{~mm}$} \\
\hline Date & $22 / 04$ & $23 / 04$ & $24 / 04$ & $25 / 04$ & $26 / 04$ & $27 / 04$ & $28 / 04$ & $29 / 04$ & $30 / 04$ & $1 / 05$ \\
\hline Mean & 14.8 & 14.8 & 13.5 & 14.4 & 14.3 & 12.5 & 12.2 & 14.2 & 14.5 & 12.4 \\
\hline Minimum & 6.8 & 11.2 & 10.2 & 7.6 & 10.7 & 9.1 & 6.1 & 6.3 & 6.6 & 5.6 \\
\hline \multicolumn{5}{|c|}{$\begin{array}{l}\text { Total rain in last week before treatment: } 4.7 \mathrm{~mm} \\
\text { First rainfall after treatment, date: } 23 / 04 / 2014\end{array}$} & \multicolumn{6}{|c|}{$\begin{array}{l}\text { Total rain in 1st week after treatment: } 23.1 \mathrm{~mm} \\
\text { Total rain in 2nd week after treatment: } 4.7 \mathrm{~mm} \\
\text { Total rain in 3rd week after treatment: } 16.0 \mathrm{~mm} \\
\text { Total rain in 4th week after treatment: } 15.3 \mathrm{~mm}\end{array}$} \\
\hline \multicolumn{11}{|c|}{ Application time: 16 June 2014} \\
\hline \multicolumn{3}{|c|}{ Temperature: $17.9^{\circ} \mathrm{C}$} & \multicolumn{4}{|c|}{$\begin{array}{c}\text { Air humidity: } 37 \% \\
\text { Temperature after treatment }\end{array}$} & \multicolumn{4}{|c|}{ Rainfall: $0.0 \mathrm{~mm}$} \\
\hline Date & $16 / 06$ & $17 / 06$ & $18 / 06$ & $19 / 06$ & $20 / 06$ & $21 / 06$ & $22 / 06$ & $23 / 06$ & $24 / 06$ & $25 / 06$ \\
\hline Mean & 15.1 & 16.4 & 17.0 & 14.2 & 13.6 & 12.9 & 13.8 & 12.6 & 12.6 & 13.5 \\
\hline Minimum & 5.8 & 9.7 & 7.0 & 8.6 & 8.9 & 9.0 & 10.0 & 7.3 & 5.6 & 7.7 \\
\hline \multicolumn{5}{|c|}{$\begin{array}{l}\text { Total rain in last week before treatment: } 25.0 \mathrm{~mm} \\
\text { First rainfall after treatment, date: } 20 / 06 / 2014\end{array}$} & \multicolumn{6}{|c|}{$\begin{array}{l}\text { Total rain in 1st week after treatment: } 6.5 \mathrm{~mm} \\
\text { Total rain in 2nd week after treatment: } 8.6 \mathrm{~mm} \\
\text { Total rain in 3rd week after treatment: } 2.3 \mathrm{~mm} \\
\text { Total rain in 4th week after treatment: } 38.1 \mathrm{~mm}\end{array}$} \\
\hline
\end{tabular}

Weed control efficacy of the tested herbicides was assessed 4 weeks after postemergence treatment by estimating reduction in weed fresh biomass (biomass was recorded from two randomly selected rectangles, $70 \mathrm{~cm} \times 50 \mathrm{~cm}$, from each plot) from herbicide treatment compared to untreated control, using the Henderson-Tilton formula. The formula applied was \% weed reduction $=(1-(\mathrm{N}$ in the control plot before treatment $\times \mathrm{N}$ in treated plot after treatment)/(N in the control plot after treatment $\times \mathrm{N}$ in treated plot before treatment)), where $\mathrm{N}=\%$ weed fresh biomass and untreated plot $=$ no herbicide treatment [27]. Impact of herbicides on maize grain yield was determined by harvesting the two central rows of each plot and expressed at 15\% moisture level, and net return of weed control was additionally assessed. Net return was computed according to value of increase of maize grain yield from herbicide treatments compared to untreated control, taking into account the cost of applied herbicides and adjuvants. In both years, the cost of their application was the same, $9.4 € \cdot h^{-1}$, D + P $32 € \cdot h a^{-1}$ (label rate), R + N + D $22.3 € \cdot h a^{-1}, \mathrm{~T} 21.5 € \cdot h a^{-1}, \mathrm{M}+\mathrm{N} 23.1 € \cdot \mathrm{ha}^{-1}$, $\mathrm{F}+\mathrm{I} 17 € \cdot \mathrm{ha}^{-1}, \mathrm{~N} 8 € \cdot \mathrm{ha}^{-1}$, MSO $4.6 € \cdot \mathrm{ha}^{-1}$, AMN $0.3 € \cdot \mathrm{ha}^{-1}$, grain price $141 € \cdot \mathrm{t}^{-1}$ in 2013 and $162 € \cdot \mathrm{t}^{-1}$ in 2014. Calculations were done basing upon average prices of grain of maize in 2013 and 2014, herbicides, adjuvants, and cost of their application (average 2013-2014) obtained from local cooperative elevator and farm supply.

Statistical procedures were conducted using Statistica 12 software (StatSoft Polska Ltd., Kraków, Poland). Raw data were transformed to arc sine square root to stabilize error variance before analysis even though all means are presented in their original units. Significant differences among treatments were determined using analysis of variance (ANOVA), and means were separated by protected Tuckey's HSD test at $p=0.05$. The untreated check was not included in the weed control analysis. Year by year treatment interactions were not significant, so 2013 and 2014 data are presented separately.

\section{Results}

In both years, the weather conditions rather advantageously affected the growth and development of maize plants as only temporarily low rainfall deficit of water was observed in July, August, and September in 2013 and in July 2014 (data not shown).

The most common species occurring in both years (Table 3) were common lambsquarter (Chenopodium album L.), barnyardgrass (Echinochloa crus-galli (L.) Pal. Beauv.), black bindweed 
(Polygonum convolvulus L.), field pansy (Viola arvensis Murr.), common fumitory (Fumaria officinalis L.), and cornflower (Centaurea cyanus L.). During field study, they were also recorded as occurring, as were a small number of weeds species like common chickweed (Stelaria media (L.) Vill.), shepherd's purse (Capsella bursa-pastoris (L.) Medicus), purple dead-nettle (Lamium purpureum L.), quackrass (Elymus repens (L.) Gould), cleavers (Galium aparine L.), field penny-cress (Thlaspi arvense L.), common poppy (Papaver rhoeas L.), corn chamomile (Anthemis arvensis L.), and knotgrass (Polygonum aviculare L.). In 2013, total fresh weight of weed was $2272 \mathrm{~g} \cdot \mathrm{m}^{-2}$ and was $7290 \mathrm{~g} \cdot \mathrm{m}^{-2}$ in 2014 (Table 4). Activity of $\mathrm{D}+\mathrm{P}$ applied pre-emergency at label and reduced rate, even in the case of $25 \%$ and $50 \%$ reduction of active ingredient, was high, and they effectively controlled all weeds in both years. Efficacy ranged from $91 \%$ to $100 \%$, except for field pansy in 2013-efficacy under $64 \%$-and common lambsquarter in 2013 at $425+500 \mathrm{~g} \cdot \mathrm{ha}^{-1}-78 \%$ (Table 3).

Table 3. Influence of dimethanamid + pendimathalin and their mixtures with postemergence herbicide on weed control.

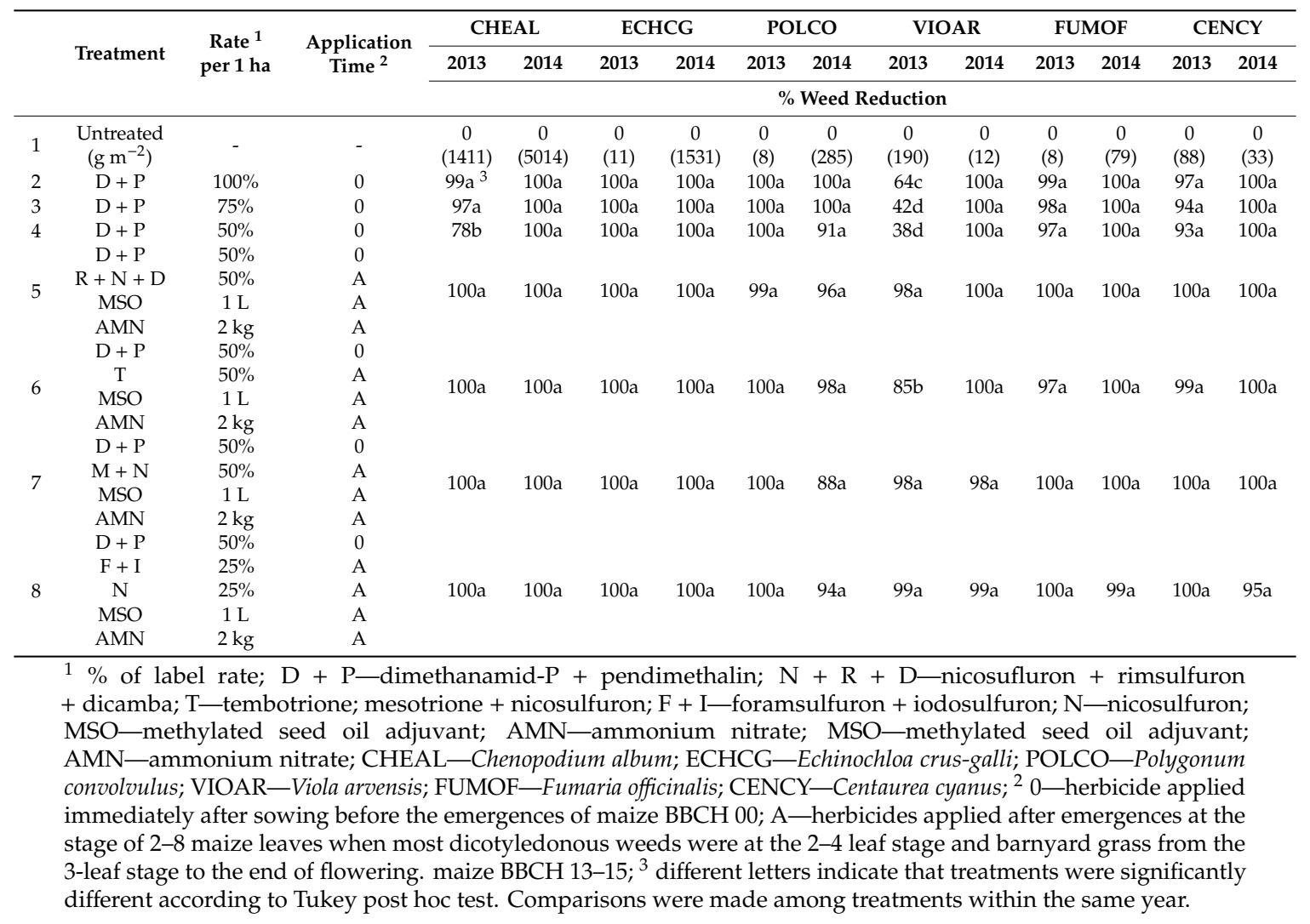

Mixtures of D $+\mathrm{P}$ and postemergence herbicides applied with MSO and AMN were very effective (treatments 5-8), reducing weed fresh mass in many cases over $94 \%$ (Table 3). Only the mixture of $\mathrm{D}+\mathrm{P}$ with adjuvants and tembotrione (treatment 6) in 2013 controlled less effectively field pansy (85\%), and mixture $\mathrm{D}+\mathrm{P}$ with adjuvants, mesotrione, and nicosulfuron in 2014 controlled black bindweed effectively but showed a slightly lower efficacy-88\%. D + P applied preemergence, at each rate in 2013 , poorly controlled field pansy, only up to $68 \%$ and, in $2014,100 \%$.

Addition of MSO and AMN adjuvants to herbicides, especially with multiple active ingredients having multiple site of action, even applied at reduced rates, can lead to great total control (Table 4). Split application of mixtures of pre- and postemergence herbicides caused increase of grain maize yield by 7.0-7.8 in 2013 and by 7.9-8.8 t.ha ${ }^{-1}$ in 2014 compared to untreated check (Table 4). Grain yield after only preemergence herbicide application (treatments 2-4) in 2013 was slightly lower compared to pre- and postemergence application (treatments 5-8), even though no significant differences were found. Moreover, treatments 2-4 in 2013 showed grain yield values similar to that recorded in 2014 . 
Application of mixtures of pre- and postemergence herbicides led to great weed control (Table 4), an increase of value of grain yield enhancement and net return, in spite of $28 \%-40 \%$ higher cost of weed control (Table 5). The net return index was similar or higher: in 2013, about 3\%-4\% and $68-91 € \cdot$ ha $^{-1}$ and, in 2014 , up to $7 \%$ and up to $106 € \cdot$ ha $^{-1}$ than from D + P at label rate. Generally, independently of slight differences between years, better activity of pre- and postemergence applied herbicides and, simultaneously, low usage of active ingredients were observed (Table 4).

Table 4. Influence of herbicides on weed control and grain yield.

\begin{tabular}{|c|c|c|c|c|c|c|c|c|}
\hline & \multirow[t]{2}{*}{ Treatment } & \multirow[t]{2}{*}{$\begin{array}{c}\text { Rate }^{1} \\
\text { per } 1 \text { ha }\end{array}$} & \multirow[t]{2}{*}{$\begin{array}{l}\text { Application } \\
\text { Time }^{2}\end{array}$} & \multirow{2}{*}{$\begin{array}{c}\text { Total Rate } \\
\text { of a.i. } \\
\mathrm{g} \mathrm{ha}^{-1}\end{array}$} & \multicolumn{2}{|c|}{$\begin{array}{c}\text { Total Weed Reduction }{ }^{3} \\
\%\end{array}$} & \multicolumn{2}{|c|}{$\begin{array}{l}\text { Grain Yield } \\
t \cdot h a^{-1}\end{array}$} \\
\hline & & & & & 2013 & 2014 & 2013 & 2014 \\
\hline 1 & Untreated & - & - & 0 & 0 & 0 & $9.4 b$ & $1.6 \mathrm{~b}$ \\
\hline 2 & $\mathrm{D}+\mathrm{P}$ & $100 \%$ & 0 & 1850.0 & $86 a^{4}$ & $97 a$ & $16.4 \mathrm{a}$ & $9.6 \mathrm{a}$ \\
\hline 3 & $\mathrm{D}+\mathrm{P}$ & $75 \%$ & 0 & 1387.5 & $74 b$ & $96 a$ & $14.8 \mathrm{a}$ & $10.5 a$ \\
\hline \multirow[t]{2}{*}{4} & $D+P$ & $50 \%$ & 0 & 925.0 & $59 c$ & $86 b$ & $14.3 a$ & $10.2 \mathrm{a}$ \\
\hline & $\mathrm{D}+\mathrm{P}$ & $50 \%$ & 0 & & & & & \\
\hline \multirow{4}{*}{5} & $\mathrm{R}+\mathrm{N}+\mathrm{D}$ & $50 \%$ & A & 1038.1 & $99 a$ & $95 \mathrm{ab}$ & $17.2 \mathrm{a}$ & $9.6 a$ \\
\hline & MSO & $1 \mathrm{~L}$ & A & 1038.1 & 9ya & yьab & $17.2 \mathrm{a}$ & $9.6 a$ \\
\hline & AMN & $2 \mathrm{~kg}$ & $\mathrm{~A}$ & & & & & \\
\hline & $\mathrm{D}+\mathrm{P}$ & $50 \%$ & 0 & & & & & \\
\hline \multirow{4}{*}{6} & $\mathrm{~T}$ & $50 \%$ & A & & & & & \\
\hline & MSO & $1 \mathrm{~L}$ & A & 958.0 & $95 a$ & $93 a b$ & $17.2 \mathrm{a}$ & $9.5 a$ \\
\hline & AMN & $2 \mathrm{~kg}$ & $\mathrm{~A}$ & & & & & \\
\hline & $\mathrm{D}+\mathrm{P}$ & $50 \%$ & 0 & & & & & \\
\hline \multirow{5}{*}{7} & $\mathrm{M}+\mathrm{N}$ & $50 \%$ & A & & & & & \\
\hline & MSO & $1 \mathrm{~L}$ & A & 977.5 & $99 a$ & $95 a b$ & $17.1 \mathrm{a}$ & $10.4 a$ \\
\hline & $\mathrm{AMN}$ & $2 \mathrm{~kg}$ & A & & & & & \\
\hline & $\mathrm{D}+\mathrm{P}$ & $50 \%$ & 0 & & & & & \\
\hline & $\mathrm{F}+\mathrm{I}$ & $25 \%$ & A & & & & & \\
\hline \multirow[t]{3}{*}{8} & $\mathrm{~N}$ & $25 \%$ & A & 947.75 & $99 a$ & $96 a$ & $16.4 \mathrm{a}$ & $9.7 \mathrm{a}$ \\
\hline & MSO & $1 \mathrm{~L}$ & A & & & & & \\
\hline & AMN & $2 \mathrm{~kg}$ & A & & & & & \\
\hline
\end{tabular}

$1 \%$ of label rate; a.i.-active ingredient of herbicide; $\mathrm{D}+\mathrm{P}$-dimethanamid-P + pendimethalin; $\mathrm{N}+\mathrm{R}+$ $\mathrm{D}$-nicosulfuron + rimsulfuron + dicamba; T-tembotrione; mesotrione + nicosulfuron; F + I-foramsulfuron + iodosulfuron; $\mathrm{N}$-nicosulfuron; $\mathrm{MSO}$ — methylated seed oil adjuvant; AMN—ammonium nitrate; ${ }^{2} 0$ — herbicide applied immediately after sowing before the emergences of maize BBCH 00; $\mathrm{A}$-herbicides applied after emergences at the stage of 2-8 maize leaves when most dicotyledonous weeds were at the 2-4 leaf stages and barnyard grass from the 3-leaf stage to the end of flowering. maize BBCH $13-15 ;{ }^{3}$ base on all weed species occurring during field study; ${ }^{4}$ different letters indicate that treatments were significantly different.

Table 5. Influence of herbicides on economic indexes.

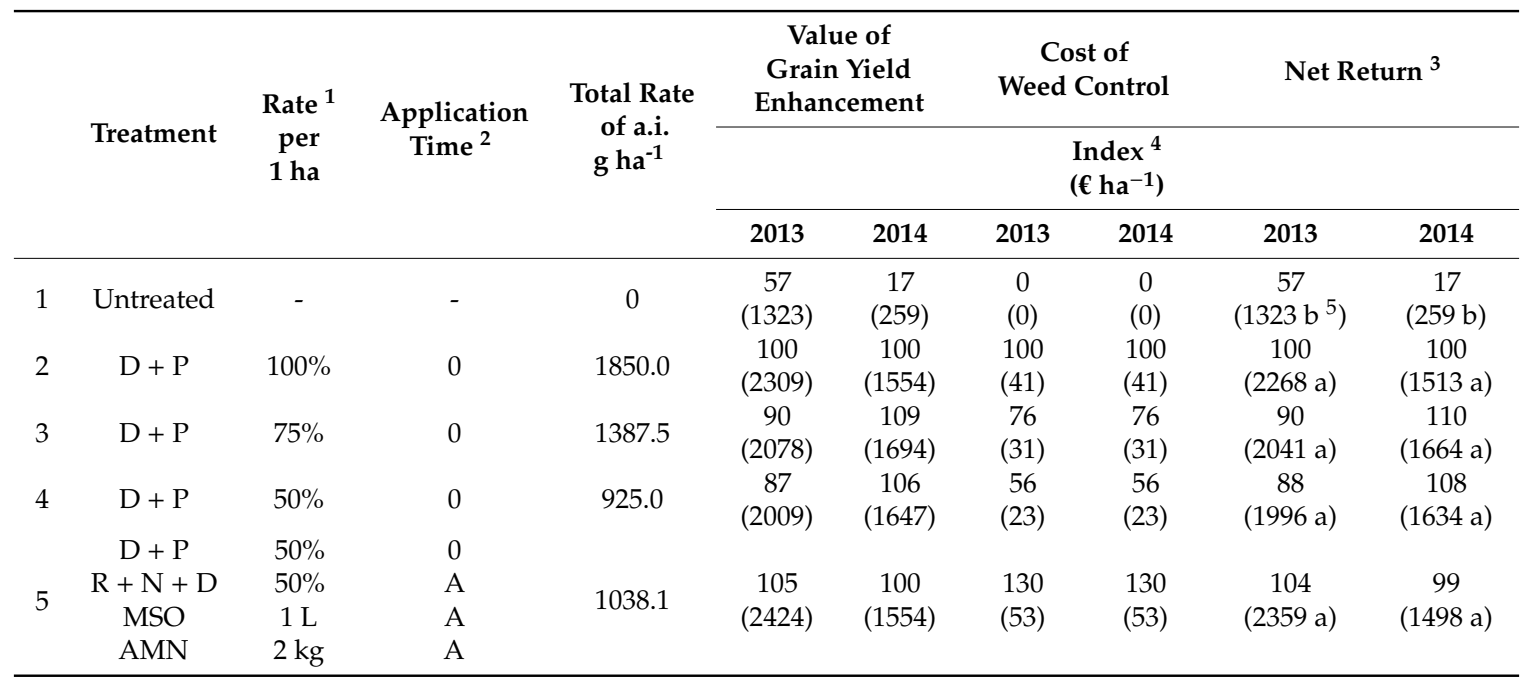


Table 5. Cont.

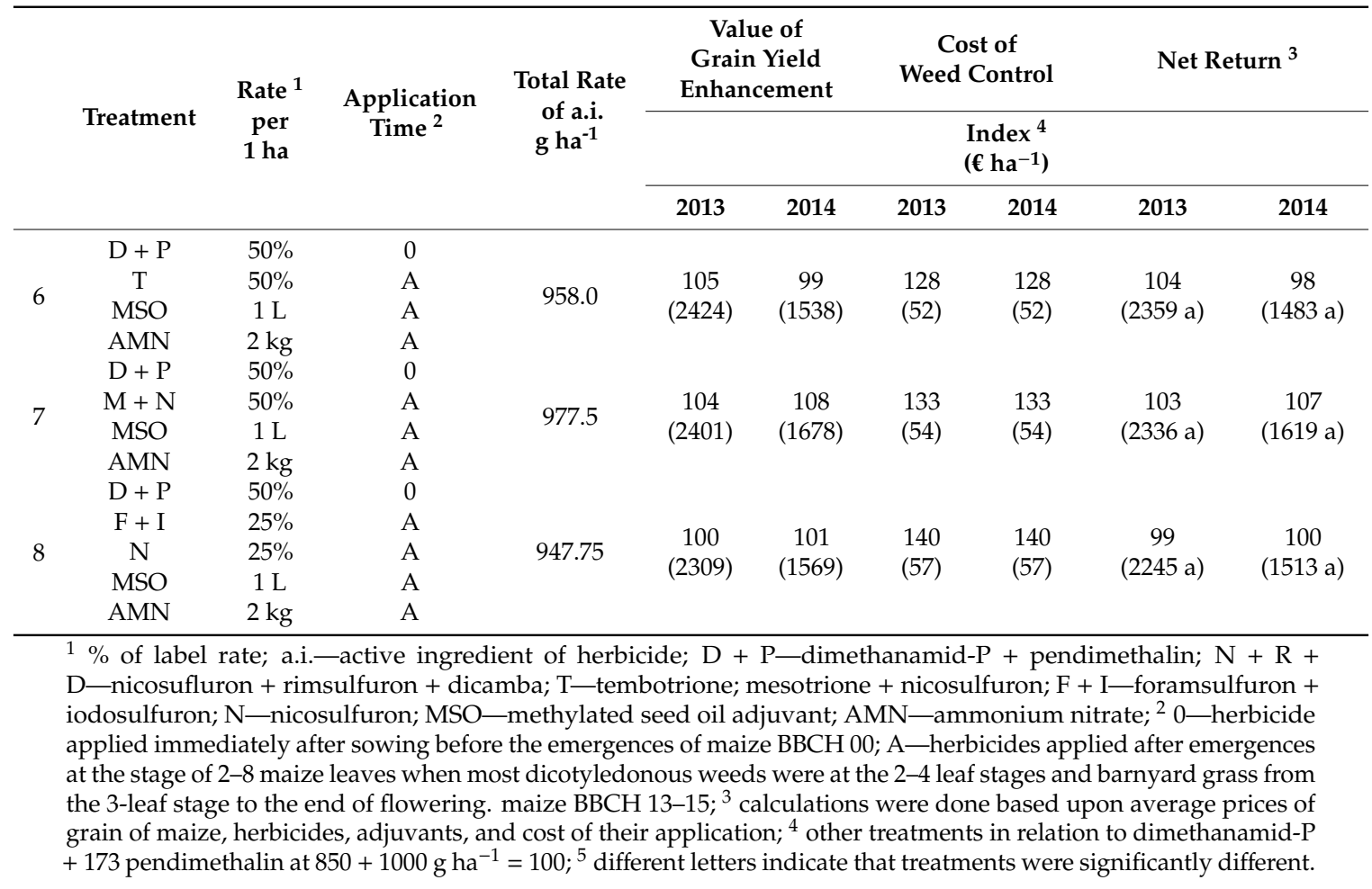

\section{Discussion}

Maize plant growth and development depend on the temperature and rainfall during vegetation season [28] similar to weed plants that also react to weather changes, but their response usually has higher plasticity [29]. Generally, weather conditions during field experiments were rather favourable for both maize and weed species plants.

Weed control efficacy depends on selected herbicides, weed community, their physiological condition, and weather conditions during and after application [30]. Activity of herbicides varies depending on uptake of active ingredients. The better physiological condition of weeds, the better uptake of herbicides is observed; therefore, generally, optimal temperature for best weed control ranges from 10 to $25^{\circ} \mathrm{C}$ or even over $30^{\circ} \mathrm{C}$ [31] and higher relative humidity [32]. Temperature influences herbicide activity because it affects their solubility, volatility, sorption, desorption, and high humidity, slowing evaporation of herbicide from a plant surface and increasing its performance [33,34]. Precipitation before and after, first of all for preemergence herbicide application, was rather beneficial for herbicide action. Weather conditions during and after treatments finally fostered the activity of herbicide, especially applied with adjuvants.

Knowledge of weed community structure is essential for effective weed control [35]. A single herbicide does not usually control all weeds species; therefore, combination of herbicides or sequential treatments are required. Properly selected herbicides, especially those containing substances with different sites of action, allow effective control over a wide range of weed species, and it is an element of strategy for herbicide-resistance weed management [36]. The mixtures of herbicides at reduced rates can be an effective strategy to manage the problem of resistance development in weeds but only when they are really as effective as herbicides applied at label rates. Weed resistance is unlikely to occur in such situations. For better efficacy during critical periods for weed control, the use of split rates of postemergence herbicides is indicated [37]. Expansion of this idea is application with preand postemergence herbicides. A preemergence herbicide applied at a strong reduced rate is used to reduce weed infestation emerging with maize to protect yield from early season weed competition (residual weed control) but it may not guarantee proper weed control at critical stage of maize growth 
and development at about the 15-leaf stage of maize [38], although during our study it controlled unexpectedly well. Weather conditions, particularly precipitation amount and timing, and soil moisture influence the efficacy of preemergence herbicides. It is important especially when reduce rates are used. Under unfavourable application conditions, the treatment should be postponed and replaced by a postemergence one. Postemergence herbicides should be used against new emergence of weeds when they are at the 2-4 leaves stages. In both years, split application led to great control of all weeds occurring during the study. Use of postemergence herbicides at reduces rates is also one of the most essential tools to limit herbicide input into the environment [39].

Herbicide efficacy depended more on growth stage of weeds [40], but other studies pointed also to factors such as weather conditions [41]. Weed control can be improved by the addition of well-chosen adjuvants, which will be able to overcome factors hindering retention of spray droplets on the surface of weed, thereafter absorption and transport to the place of action [19,42]. Compounds of used blend adjuvants enhance emulsifying, dispersing, spreading, sticking, or wetting properties of herbicides; give quicker absorption and solvent of cuticular waxes; reduce loss of carrier during and after application; affect the half-life solubility; and buffer and control $\mathrm{pH}$ in the tank mix, preventing herbicides from being degraded by hydrolysis in aqueous solutions $[43,44]$. Our results indicated that a properly selected adjuvant, based on emulsified methylated seed oil, in this case rapeseed oil fatty acids with surfactants and $\mathrm{pH}$ buffer (multifunctional adjuvant), had a positive impact on the herbicides. Further improvement of herbicide activity can be achieved by use of nitrogen fertilizers as mineral adjuvants, for instance ammonium nitrate, also together with other adjuvants [45]. Mineral adjuvants increase droplet retention and spreading, improve rainfastness, and enhance absorption and translocation of active ingredients [15,46-48]. Relatively polar, weak acid herbicides such as sulfonylureas or imidazolinones are usually applied with addition of ammonium salts. In this trial, the great efficacy of split applied herbicides at strongly reduced rates primarily resulted from the addition of MSO and mineral adjuvants. This way, effective tank-mixtures reduce selection of herbicide-resistant biotypes more successfully than rotating herbicide mode of action [49].

The obtained data indicate that herbicides applied at mixtures with adjuvants greatly controlled weeds but that the costs of split application of herbicides were much higher than only preemergence application. However, the value of maize grain yield and net return was also higher. Taking into consideration both high herbicidal efficacy and growth in the value of grain yield, the profitability of these treatments was higher than expected.

\section{Conclusions}

Weed infestation is a supremely important factor that is responsible for low maize grain yield [50]. Split application of various herbicides usually contributed to the increase in yield stronger than a single treatment. Results from our studies indicated that, due to elimination of weeds, both single and split application of herbicides with MSO and AMN adjuvants caused grain yield increase compared to untreated control. Considering a high herbicidal efficacy and, consequently, a growth in the value of grain yield harvested, the profitability of using herbicide mixtures with an addition of adjuvants was higher than that using comparative herbicides at one time. However, final results depend on herbicides in the mixture and may slightly vary in years. The split application of herbicides on weeds in the period of their highest sensitivity can be admittedly beneficial in economic terms due to the lower usage of active ingredients.

Author Contributions: Conceptualization, R.I. and Z.W.; methodology, R.I. and Z.W.; software, R.I.; validation, R.I.; formal analysis, R.I. and Z.W.; investigation, R.I.; resources, R.I.; data curation, R.I.; writing一original draft preparation, R.I.; writing - review and editing, Z.W.; visualization, R.I.; supervision, Z.W.; project administration, R.I. All authors have read and agreed to the published version of the manuscript.

Funding: The paper was financed within the framework of Ministry of Science and Higher Education programme 'Regional Initiative of Excellence' in years 2019-2022, Project No. 005/RID/2018/19. 
Acknowledgments: The authors are grateful for support provided by the Poznań University of Life Sciences, Poland including technical support and materials used for field experiments.

Conflicts of Interest: The authors declare no conflict of interest.

\section{References}

1. GUS. Agriculture in 2018. Statistics Poland. Statistical Analyses. Warsaw. Available online: https://stat. gov.pl/obszary-tematyczne/rolnictwo-lesnictwo/rolnictwo/rolnictwo-w-2018-roku,3,15.html (accessed on 6 November 2019).

2. FAOSTAT. Crops. Food and Agriculture Organization of the United Nations. Statistic Division. Available online: http://faostat3.fao.org (accessed on 13 December 2019).

3. Horvath, D.P.; Bruggeman, S.; Moriles-Miller, J.; Anderson, J.V.; Dogramaci, M.; Scheffler, B.E.; Hernandez, A.G.; Foley, M.E.; Clay, S. Weed presence altered biotic stress and light signalling in maize even when weed were removed early in the critical weed-free period. Plant Direct. 2018, 2, 1-15. [CrossRef] [PubMed]

4. Idziak, R.; Woznica, Z. Effect of nitrogen fertilizers and oil adjuvants on nicosulfuron efficacy. Turk. J. Field Crops 2013, 18, 174-178.

5. Isik, D.; Mannan, H.; Bukan, B.; Oz, A.; Ngauajiro, M. The critical period for weed control in corn in Turkey. Weed Technol. 2006, 20, 867-872. [CrossRef]

6. Mahmoodi, S.; Rahimi, A. Estimation of critical period for weed control in corn in Iran. Int. J. Agric. Eng. Technol. 2009, 49, 67-72.

7. Ghanizadeh, H.; Lorzadeh, S.; Ariannia, N. Critical period for weed control in corn in the south-west of Iran. Asian J. Agric. Res. 2000, 4, 80-86. [CrossRef]

8. Williams, M.M. Biological significance of low weed population densities on sweet corn. Agron. J. 2010, 102, 464-468. [CrossRef]

9. Zystro, J.P.; de Leon, N.; Tracy, W.F. Analysis of traits related to weed competitiveness in sweet corn (Zea mays L.). Sustainability 2012, 4, 543-560. [CrossRef]

10. Safdar, M.E.; Asif, M.; Ali, A.; Aziz, A.; Yasin, M.; Aziz, M.; Afzal, M.; Ali, A. Comparative efficacy of different weed management strategies in wheat. Chil. J. Agric. Res. 2011, 71, 195-204. [CrossRef]

11. Ali, R.; Khalil, S.K.; Raza, S.M.; Khan, H. Effect of herbicides and row spacing on maize (Zea mays L.). Pak. J. Weed Sci. Res. 2003, 9, 171-178.

12. Felisberto, P.A.C.; Felisberto, G.; Ramos, A.R.; Timossi, P.C. Maize crop phytotoxicity in response to sub-doses of suflometuron-methyl. Planta Daninha 2017, 35, e017166504. [CrossRef]

13. Kughur, P.G. The effects of herbicides on crop production and environment in Makurdi local government area of Benue state, Nigeria. J. Sustain. Dev. Africa 2012, 14, 206-2016.

14. Price, A.J.; Balkcom, K.S.; Culpepper, S.A.; Kelton, J.A.; Nichols, R.L.; Schomberg, H. Glyphosate-resistant Palmer amaranth: A threat to conservation tillage. J. Soil Water Conserv. 2011, 6, 265-275. [CrossRef]

15. Zollinger, R.; Christoffers, M.; Dalley, C.; Endres, G.; Gramig, G.; Howatt, K.; Jenks, B.; Lym, R.; Ostlie, M.; Peters, T.; et al. Corn. In North Dakota Weed Control Guide; North Dakota Agricultural Experiment Station Fargo: Fargo, ND, USA, 2015; pp. 18-24.

16. ZOR. Kukurydza. In Zalecenia Ochrony Roslin na lata 2018/19. Cz. II Rosliny rolnicze; IOR-PIB Poznan: Poznań, Poland, 2018; pp. 102-110.

17. Vahedi, A.; Bakhshi, Z.; Fakhari, R.; Vahidipour, H.R. Evaluation of competitiveness of corn and pigweed in nitrogen levels under pigweed densities by corn yield converse relations. Int. J. Agric. Crop Sci. 2013, 5, 1442-1444.

18. Kudsk, P. Optimising herbicide performance. In Weed Management Handbook; Naylor, R.E.L., Ed.; Blackwell Publishing: Oxford, UK, 2002; pp. 323-344.

19. Woznica, Z.; Idziak, R. Influence of reduced rates of herbicides applied with adjuvants at various dates on weed control and yield of maize. Fragm. Agron. 2015, 32, 111-118.

20. Kierzek, R.; Paradowski, A.; Pietryga, J.; Kaczmarek, S. Effectiveness of weed control in maize with two foliage treatments. Prog. Plant Prot. 2013, 53, 471-476.

21. Knezevic, S.Z. Critical period for weed control: The concept and data analysis. Weed Sci. 2002, 50, 773-786. [CrossRef] 
22. Sunitha, N.; Reddy, P.M.; Sadhineni, M. Effect of cultural manipulation and weed management practices on weed dynamics and performance of sweet corn (Zea mays L.). Indian J. Weed Sci. 2010, 42, 184-188.

23. Idziak, R.; Woznica, Z. Efficiency assessment of limited doses of herbicide mixtures applied with adjuvants in maize protection. Acta Sci. Pol. Agric. 2010, 9, 17-28.

24. Dogan, M.N.; Unay, A.; Boz, O.; Albay, F. Determination of optimum weed control timing in maize (Zea mays L.). Turk. J. Agric. For. 2004, 28, 349-354.

25. Zhang, J.; Zheng, L.; Jack, O.; Yan, D.; Zhang, Z.; Gerhards, R.; Ni, H. Efficacy of four post-emergence herbicides applied at reduced doses on weeds in summer maize (Zea mays L.) fields in North China Plain. Crop. Prot. 2013, 52, 26-32. [CrossRef]

26. Akhter, M.J.; Abbas, R.N.; Waqas, M.A.; Noor, M.A.; Arshad, M.A.; Mahboob, W.; Nadeem, F.; Azam, M.; Gull, U. Adjuvant improves the efficacy of herbicide for weed management in maize sown under altered sowing methods. J. Exp. Biol. Agric. Sci. 2017, 5, 22-30. [CrossRef]

27. Bailey, K.L.; Falk, S.; Derby, J.; Melzer, M.; Boland, G.J. The effect of fertilizers on the efficacy of the bioherbicide, Phoma macrostoma, to control dandelions in turfgrass. Biol. Control 2013, 65, 147-151. [CrossRef]

28. Hatfield, J.L.; Takle, G.; Grothjahn, R.; Holden, P.; Izaurralde, R.C.; Mader, T.; Marshall, E.; Liverman, D. Ch. 6. Agriculture. In Climate Change Impacts in the United States; Melillo, J.M., Richmond, T.C., Yohe, G.W., Eds.; The Third National Climate Assessment: Washington, DC, USA, 2014; pp. 150-174.

29. Pilipavicius, V. Influence of climate change on weed vegetation. In Global Warming. Causes, Impacts and Remedies; Singh, B.R., Ed.; IntechOpen: London, UK, 2015; pp. 89-114.

30. Nalewaja, J.D.; Matysiak, R. Influence of diammonium sulphate and other salts on glyphosate phytotoxicity. Pestic. Sci. 1993, 38, 77-84. [CrossRef]

31. Matzenbacher, F.O.; Vidal, R.A.; Merotto, J.R.; Trezzi, M.M. Environmental and physiological factors that affect the efficacy of herbicides that inhibit the enzyme protoporphyrinogen oxidase: A literature review. Planta Daninha Viçosa-MG 2014, 32, 457-463. [CrossRef]

32. Ramsey, R.J.L.; Stephenson, G.R.; Hall, J.C. Effect of relative humidity on the uptake, translocation, and efficacy of glufosinate ammonium in wild oat (Avena fatual). Pestic. Biochem. Phys. 2002, 73, 1-8. [CrossRef]

33. Mphundi, P.; Allemann, J. Effect of temperature on maize sensitivity to acetochlor. In Proceedings of the Second RUFORUM Biennial Regional Conference on Building Capacity for Food Security in Africa, Entebbe, Uganda, 20-24 September 2010; Adipala, E., Tusiime, G., Majaliwa, M.J.G., Eds.; RUFORUM Working Document Series nr 5. Regional Universities Forum for Capacity Building in Agriculture (RUFORUM): Kampala, Uganda, 2010; pp. 213-218.

34. Ramsey, R.J.L.; Stephenson, G.R.; Hall, J.C. A review of the effects of humidity, humectants, and surfactant composition on the absorption and efficacy of highly water-soluble herbicides. Pestic. Biochem. Phys. 2005, 82, 162-175. [CrossRef]

35. Dewey, S.A.; Andersen, K.A. Distinct roles of surveys, inventories, and monitoring in adaptive weed management. Weed Technol. 2004, 18, 1449-1452. [CrossRef]

36. Vrbnicanin, S.; Pavlovic, D.; Bozic, D. Ch. 2. Weed resistance to herbicides. In Herbicide Resistance in Weeds and Crops; Pacanoski, Z., Ed.; IntechOpen: London, UK, 2017; pp. 7-35.

37. Idziak, R.; Woznica, Z. Impact of tembotrione and flufenacet plus isoxaflutole application timings, rates, and adjuvants type on weeds and yield of maize. Chil. J. Agric. Res. 2014, 74, 129-134. [CrossRef]

38. Kierzek, R.; Paradowski, A.; Kaczmarek, S. Chemical methods of weed control in maize (Zea mays L.) in variable weather conditions. Acta Sci. Pol. Agric. 2012, 11, 35-52.

39. Swanton, C.J.; Weise, S.F. Integrated weed management: The rationale and approach. Weed Technol. 1991, 5, 657-663. [CrossRef]

40. Kieloch, R.; Kucharski, M. Evaluation of the possibility of tribenuron methyl dose limitation in relation to selected abiotic factors and growth stage of weeds. Prog. Plant Prot. 2015, 55, 461-465.

41. WCG. Weed control principles. In Weed Control Guide for Ohio, Indiana and Illinois; Pub\# WS16/Bulletin Purdue University: Lafayette, IN, USA, 2015; pp. 1-15.

42. Sobiech, L.; Idziak, R.; Woznica, Z.; Skrzypczak, G. Effect of various adjuvants on physicochemical properties and control efficiency of herbicides. Przem. Chem. 2014, 93, 945-947.

43. McMullan, P.M. Utility adjuvants. Weed Technol. 2000, 14, 792-797. [CrossRef]

44. Tu, M.; Hurd, C.; Randall, J.M. Weed Control Methods Handbook: Tools E Techniques for Use in Natural Areas; All U.S. Government Documents (Utah Regional Depository): Logan, UT, USA, 2001; p. 533. 
45. Somervaille, A.; Betts, G.; Gordon, B.; Green, V.; Burgis, M.; Henderson, R. Adjuvants—Oils, Surfactants and Other Additives for Farm Chemicals. Grains Research \& Development Corporation; Australian Government Kingston ACT: Canberra, Australia, 2012; pp. 1-52.

46. McWhorter, C.G.; Ouzts, C.; Hanks, J.E. Spread of water and oil droplets on johngrass (Sorhgum halepense) leaves. Weed Technol. 1993, 4, 460-467. [CrossRef]

47. Mercier, L.; Serre, I.; Cabanne, F.; Gauvrit, C. Behaviour of alkyl oleates following foliar application in relation to their influence on the penetration of phenmedipham and quizalofop-P-ethyl. Weed Res. 1997, 37, 267-276. [CrossRef]

48. Miller, P.A.; Westra, P.; Nissen, S.J. The influence of surfactant and nitrogen on foliar absorption of MON 37500. Weed Sci. 1999, 47, 207-274. [CrossRef]

49. Chikoye, D.; Schulz, S.; Ekeleme, F. Evaluation of integrated weed management practices for maize in the northern Guinea savanna of Nigeria. Crop Prot. 2004, 23, 895-900. [CrossRef]

50. Woznica, Z.; Idziak, R. Influence of herbicide application timings, rates and adjuvant type on weed control and yield of maize grown for forage. Acta Sci. Pol. Agric. 2010, 9, 77-84.

(C) 2020 by the authors. Licensee MDPI, Basel, Switzerland. This article is an open access article distributed under the terms and conditions of the Creative Commons Attribution (CC BY) license (http://creativecommons.org/licenses/by/4.0/). 